\title{
The 2nd International Symposium on Fire Blight of Rosaceous Plants: a Journal of Plant Pathology special issue
}

\author{
George W. Sundin ${ }^{1}$. Fabio Rezzonico ${ }^{2}$
}

Received: 7 July 2021 / Accepted: 7 July 2021 / Published online: 19 July 2021

(c) Società Italiana di Patologia Vegetale (S.I.Pa.V.) 2021

Fire blight disease, caused by the bacterium Erwinia amylovora, continues to negatively impact the commercial production of pome fruit and other Rosaceae plants throughout most countries of the world where these crops are grown. The pathogen has also recently spread into new countries, with the most recent being Korea in 2016 (Myung et al. 2016). Although fire blight disease has been known to be caused by a bacterium for over 140 years, the disease has proven to be extremely difficult to manage, most notably because of the very high susceptibility of most modern commercial pome fruit cultivars.

The fire blight research community is diverse, globally distributed, and active in many different topic areas including plant resistance breeding and genetics, molecular biology of host-pathogen interactions, disease management and discovery of new management tools and techniques, and $E$. amylovora genomics and population biology. For every three years since 1977, the international fire blight community has met for research symposia at locations throughout the world. Formerly organized under the auspices of the International Society for Horticultural Science, the last two symposia have been organized independently under the title: International Symposium on Fire Blight of Rosaceous Plants (ISFB). The $1^{\text {st }}$ ISFB was held in Girona, Spain in 2016 and the 2nd ISFB was held in Traverse City, Michigan (U.S.A.) in 2019. A special issue of the Journal of Plant Pathology consisting of refereed journal articles and reviews from research and ideas exchanged at the 2016 symposium was published in 2017 (Volume 99, Special Issue [http://www.sipav.org/ main/jpp/index.php/jpp/issue/view/153]). In this special

\footnotetext{
George W. Sundin

sundin@msu.edu

$\bowtie$ Fabio Rezzonico

fabio.rezzonico@zhaw.ch

1 Michigan State University, East Lansing, USA

2 ZHAW Institute of Natural Resource Sciences, Zurich, Switzerland
}

issue, we present five refereed current review articles and ten research papers emanating from work presented at the 2019 symposium.

The review articles highlight current efforts in resistance breeding for fire blight, detailed analyses of type III secretion and biofilm formation in E. amylovora, critical pathogenicity and virulence factors, respectively, early events in fire blight infection, and structure/function analyses of proteins that are critical to E. amylovora pathogenesis. Research articles cover a broad range of topics including quantitative variation in resistance in commercial apple cultivars, characterization of novel virulence factors of $E$. amylovora, a functional assessment of pathogen detection methods, disease management strategies, and analyses of E. amylovora isolates from fire blight outbreaks in central Asia.

The $2^{\text {nd }}$ ISFB was dedicated to Eve Billing (1923-2019), truly a major figure in E. amylovora and fire blight research. Dr. Billing laid the foundation for future advances with her work on varied subjects including laboratory diagnosis of fire blight (Billing et al. 1960), determining factors important for growth of E. amylovora (Billing 1974), refining fire blight disease prediction (Billing 1992), and examinations of the exopolysaccharide amylovoran (Bennett and Billing 1978, 1980). Following her retirement in 1983, Dr. Billing continued to be an active contributor to fire blight symposia for decades, and published her last paper on fire blight at the age of 87 (Billing 2011). One of us (G.W.S.) was delighted to be able to visit Dr. Billing at her home in England several times from 2012 onward (Fig. 1). Her ideas and suggestions, and critical evaluation of research projects, helped shape current research questions focused on the E. amylovora disease cycle pathogen migration through apple trees, and pathogen dissemination (Slack et al. 2017; Kharadi et al. 2021). During G. Sundin's last visit with Eve, her directive to "find a cure" has provided the motivation for the fire blight research community to continue attacking this disease from multiple host, pathogen, and disease management angles until sustainable management is achieved. 
Fig. 1 Eve Billing and George Sundin, Cirencester, UK, 2012

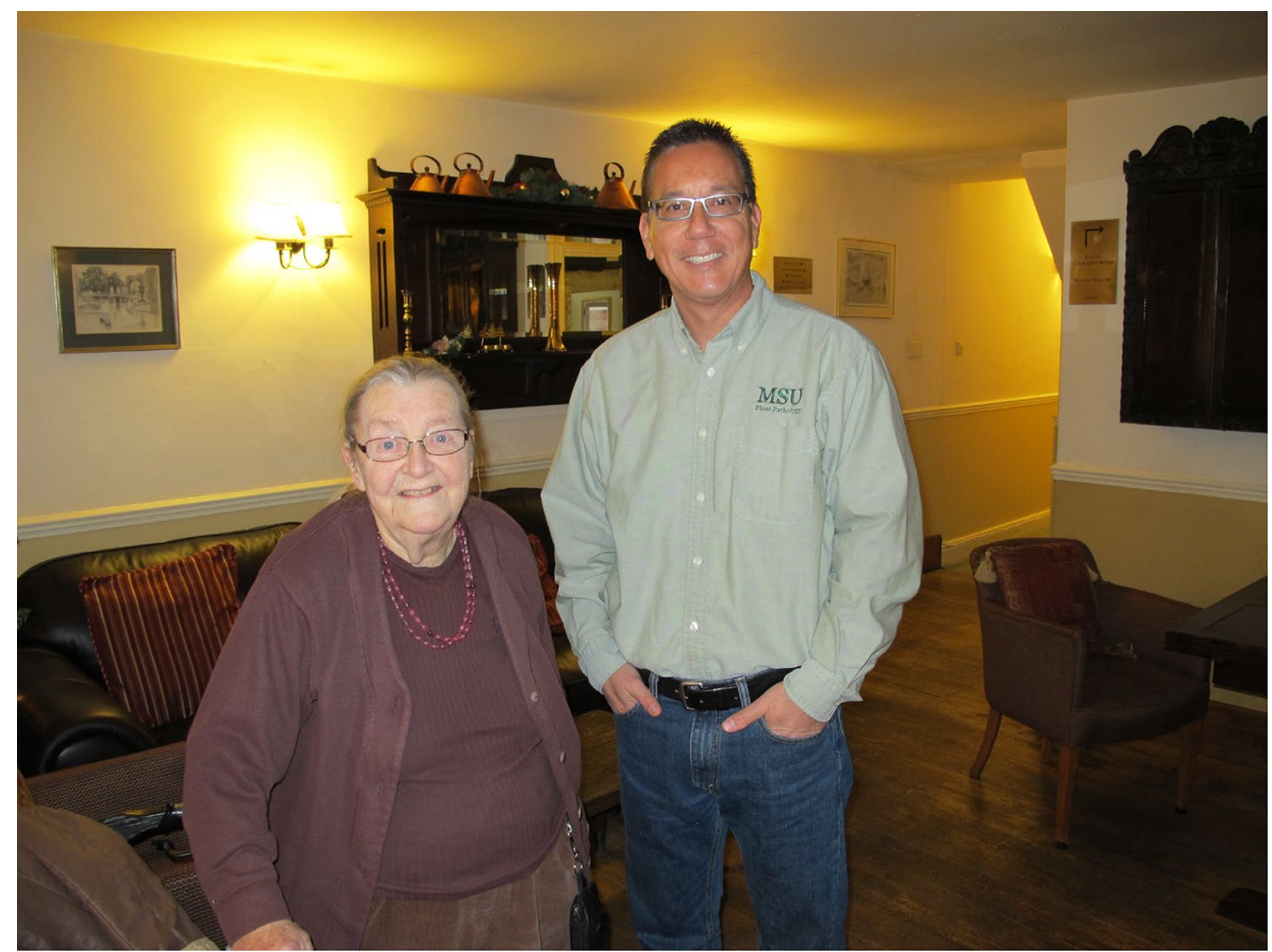

\section{References}

Bennett RA, Billing E (1978) Capsulation and virulence in Erwinia amylovora. Ann Appl Biol 89:41-45

Bennett RA, Billing E (1980) Origin of the polysaccharide component of ooze from plants infected with Erwinia amylovora. J Gen Microbiol 116:341-349

Billing E (1974) The effect of temperature on the growth of the fireblight pathogen, Erwinia amylovora. J Appl Microbiol 37:643-649

Billing E (1992) Billing's revised system (BRS) for fireblight risk assessment. EPPO Bull 22:1-102

Billing E (2011) Fire blight. Why do views on host invasion by Erwinia amylovora differ? Plant Pathol 60:178-189

Billing E, Crosse JE, Garrett CME (1960) Laboratory diagnosis of fire blight and bacterial blossom blight of pear. Plant Pathol 9:19-25
Kharadi RR, Schachterle JK, Yuan X, Castiblano LF, Peng J, Slack SM, Zeng Q, Sundin GW (2021) Genetic dissection of the Erwinia amylovora disease cycle. Annu Rev Phytopathol. https://doi.org/ 10.1146/annurev-phyto-020620-095540

Myung IS, Lee JY, Yun MJ, Lee YH, Lee YK, Park DH, Oh CS (2016) Fire blight of apple, caused by Erwinia amylovora, a new disease in Korea. Plant Dis 100:1774

Slack SM, Zeng Q, Outwater CA, Sundin GW (2017) Microbiological examination of Erwinia amylovora exopolysaccharide ooze. Phytopathology 107:403-411

Publisher's Note Springer Nature remains neutral with regard to jurisdictional claims in published maps and institutional affiliations. 